\title{
A EXPERIÊNCIA MISSIONÁRIA DA COMPANHIA DE JESUS NAS TERRAS DO CABO NORTE (AMAPÁ) NO SÉCULO XVII
}

\author{
Bruno Rafael Machado Nascimento'
}

\section{Resumo}

Este artigo tem por objetivo compreender os meandros da presença jesuítica nas terras do cabo Norte na segunda metade do século XVII. Enfocam-se as relações com os indígenas e busca-se compreendê-los como protagonistas diante do processo de colonização e catequização, ou seja, valorizou-se as suas táticas de sobrevivência. Caso emblemático analisado foram as mortes de dois missionários ocasionadas por povos indígenas que resistiram à dominação. Percebeu-se que as relações com os ameríndios foram complexas e exigiram negociações entre os envolvidos. $O$ pano de fundo que perpassa toda a pesquisa é a disputa pela posse do território contra os franceses.

Palavras chaves: Missões jesuíticas, Indígenas, Araguari.

\begin{abstract}
This article aims to understand the intricacies of the Jesuit presence in the North Cape lands in the second half of the 17th century. The focus is on relations with the indigenous people and the attempt to understand them as protagonists in the face of the colonization and catechization process, that is, their survival tactics were valued. An emblematic case analyzed was the deaths of two missionaries caused by indigenous peoples who resisted domination. Relations with the Amerindians were found to be complex and required negotiations between those involved. The background that runs through all the research is the dispute over possession of the territory against the French.
\end{abstract}

Keywords: Jesuit Missions, Indigenous, Araguari.

\footnotetext{
1 Professor de História da Secretaria Estadual de Educação do Estado do Amapá. E-mail: professorbrunohistoria8@gmail.com
} 


\section{Considerações iniciais}

Este artigo objetiva trazer à baila a experiência da Companhia de Jesus nas "terras do Cabo Norte" nos anos finais do século XVII em sua relação com os indígenas. Buscase captar as táticas de sobrevivência desses povos frente à violência da colonização e da cristianização. Não é tarefa fácil, visto que as fontes foram escritas por outros agentes coloniais e não pelos indígenas. Contudo, a partir da leitura nas entrelinhas proposta por Maria Celestino de Almeida ${ }^{3}$ é possível lançar o olhar histórico-antropológico em que se busca entender os significados das ações dos sujeitos dentro da noção de cultura entendida como algo flexível e não estático, ademais eles são vistos como protagonistas que tiveram possibilidades de ação e não como sujeitos passivos. Por conseguinte, a documentação apresenta diversas vozes, inclusive, as dos indígenas que nessas condições "aparece de maneira sutil, nas entrelinhas e sempre filtrada pela ótica dos interesses de quem os documenta." ${ }^{4}$ Assim essa perspectiva não desconsidera o etnocentrismo presente nos discursos, mas procura acessar o universo cultural indígena por meio dos vestígios, pistas, sinais presentes nas fontes. ${ }^{5}$

Obra fundamental para a elaboração da pesquisa foi a Crônica dos padres da Companhia de Jesus ${ }^{6}$ escrita pelo padre Bettendorff no final do século XVII. Seu trabalho foi um pedido dos seus superiores com a finalidade de edificação, ou seja, elevar a memória da ordem e realizar a defesa dos padres exaltando os que foram mortos como verdadeiros mártires. ${ }^{7}$ Além da obra citada anteriormente, usou-se alguns documentos do Arquivo Histórico Ultramarino adquiridos por meio da internet do projeto resgate "Barão do Rio Branco". Segundo Juciene Apolinário, os historiadores utilizam essa documentação há bastante tempo, entretanto invisibilizam os indígenas. Entretanto,

\footnotetext{
${ }^{2}$ Aqui compreendido como a região acima do rio Amazonas próximo ao "acidente geográfico" de mesmo nome.

3 ALMEIDA, Maria Regina Celestino de. História e antropologia. In: CARDOSO, Ciro Flamarion; VAINFAS, Ronaldo. Novos domínios da História. Rio de Janeiro: Elsevier, 2012. p. 151-168.

${ }^{4}$ MONTERO, Paula. Introdução. In: MONTERO, Paula (Org.). Deus na aldeia: missionários, índios e mediação cultural. São Paulo: Globo, 2006. p. 13.

${ }^{5}$ GINZBURG, Carlo. Sinais: raízes de um paradigma indiciário. In: GINZBURG, Carlo. Mitos, emblemas, sinais: morfologia e história. Tradução Frederico Carotti. São Paulo: Companhia das Letras, 2001. p. 143179.

${ }^{6}$ BETTENDORFF, João Felipe. Crônica dos Padres da Companhia de Jesus no Estado do Maranhão. Belém: Fundação Cultural do Pará Tancredo Neves/Secretaria de Estado da Cultura, 1990.

7 TORRES-LONDOÑO, Fernando. La experiencia religiosa jesuita y la crónica misionera de Pará y Maranhão en el siglo XVII. In: NEGRO, Sandro; MARZAL, Manuel (coord.). Un reino en la frontera: las misiones jesuitas en la América colonial. Quito, Ecuador: ABYA-YALA, 2000.
} 
existem "vozes dissoantes de importantes e reais sujeitos da história da América portuguesa que são os homens e mulheres indígenas." "Outra obra bibliográfica, mas que trouxe transcrições de vários documentos foi História da Companhia de Jesus ${ }^{9}$ do padre Serafim Leite que é indispensável para o estudo da ordem no Brasil.

O Cabo Norte tem a especificidade de ser uma região fronteiriça, isto é faz fronteira com a França através do seu território sul-americano chamado de Guiana Francesa. Eduardo Neumann, ao referir-se à região fronteiriça platina, afirma que por ser uma região com essa característica foi objeto de diversas experiências de reduções jesuíticas "que visavam por um lado, pacificar a população indígena e, por outro, estabelecer núcleos de povoamento para auxiliar no guarnecimento do território." ${ }^{10}$ Este espaço foi conquistado pelos portugueses paulatinamente e a custa de conflitos com ingleses, holandeses e franceses. Os ingleses e holandeses, mesmo antes dos lusitanos, construíram fortificações que serviam principalmente para o comércio com os indígenas. Chegaram a plantar tabaco, levaram madeiras, urucum, peixe-boi para a Europa. Neste processo de combates, os ameríndios aliados foram decisivos, pois eles foram os flecheiros, guias, usaram suas técnicas de guerra e sua mão de obra foi utilizada na devastação e construções de fortes. ${ }^{11}$ Depois de expulsos, holandeses e ingleses, a força foi concentrada para debelar os franceses que estavam instaurados na Guyane (atualmente Guiana Francesa), mas realizavam comércio e traficavam escravos frutos de guerras intertribais com os indígenas do Cabo Norte. Desde o final do século XVII a presença aumentou a tal ponto de reivindicarem parte do Cabo Norte como território francês. A questão só foi resolvida em dezembro de 1900 pela mediação do Barão do Rio Branco que defendeu a o Brasil contra a França. O "laudo de Berna" foi decidido pelo presidente da Confederação Helvética, Walter Hauser, que o rio Oiapoque era o limite entre as duas nações e não o Araguari como argumentavam os franceses. ${ }^{12}$

\footnotetext{
${ }^{8}$ APOLINÁRIO, Juciene Ricarte. Documentos e instrumentos de pesquisa de História indígena e do indigenismo d'aquém e d'além-mar Atlântico: uma discussão "necessária, urgente e inadiável. In: Simpósio Nacional de História da ANPUH, 26, 2011, São Paulo. Anais. São Paulo: ANPUH, 2011. p. 1-15.

${ }^{9}$ LEITE, Serafim. História da Companhia de Jesus no Brasil. Tomos II, III e IV, São Paulo: Edições Loyola, 2004.

${ }^{10}$ NEUMANN, Eduardo. Fronteira e identidade: confrontos luso-guarani na Banda Oriental 1680-1757. Revista Complutense de História da América, Madri, v, 26, p. 73-92, 2000. p. 74.

${ }^{11}$ Para aprofundar a narrativa sobre todo o processo de conquista portuguesa ver: REIS. Arthur Cezar F. Território do Amapá: perfil histórico. Rio de Janeiro: Imprensa Nacional, 1949.

${ }^{12}$ Sobre essa questão ver: REIS. Arthur Cezar F. Limites e demarcações na Amazônia brasileira: a frente colonial com a Guiana Francesa. 2. ed. v.1. Belém: SECULT, 1993.
} 


\section{A Companhia de Jesus nas "terras do Cabo Norte"}

Os primeiros religiosos a missionarem nas "terras do Cabo Norte" não foram os jesuítas, mas os capuchos de Santo Antônio que desde a primeira metade do século XVII tinham missões no Marajó e visitavam constantemente essas terras. Eles foram importantes para o governo português, pois ao estabelecer contato com os ameríndios, acabavam sendo informados da presença de outros estrangeiros e constantemente informavam às autoridades (REIS, 1949). Em carta escrita de Belém no dia 22 de janeiro de 1685, o Governador do Maranhão e Grão Pará, Francisco de Sá e Meneses, escreveu para o rei dom Pedro II sobre a presença de franceses que insistiam em fazer comércio nas terras do Cabo Norte com o povo Aruã. ${ }^{13}$ Os franceses passavam pela missão dos capuchos de Santo Antônio nas aldeias dos Tujucu para realizar tráfico de escravos indígenas para levar à Caiena. Essas informações chegaram ao conhecimento dele por meio dos franciscanos. O discurso da presença desses "estrangeiros" comercializando com os indígenas e a necessidade de proteger a região foi o fio condutor dos documentos consultados. No entanto, na década de 80 do século XVII, os jesuítas foram enviados a pedido do rei ao Cabo Norte para estabelecer missões com a finalidade de contribuir para a colonização da região.

Em resposta ao rei, no dia 2 de abril de 1680, padre Antônio Vieira escreveu ao padre Jodoco Peres que era o superior do Maranhão, pedindo que enviasse missionário antes de tudo ao Cabo Norte para "à conservação do Estado."14 Na missiva ele citou que tinha notícias que lá pela "banda do Rio Amazonas" vivia a "nação dos Tecujus."15 Apesar de estar do outro lado do Atlântico Vieira usou seu prestígio para indicar padre Aloísio Conrado Pfeil para executar a missão nas “terras do Cabo Norte”. A escolha não foi por acaso, pois o missionário suíço era considerado por seus superiores como excelente matemático, pintor e cartógrafo. ${ }^{16}$ Ao analisar o teor da missiva percebe-se a preocupação não somente com a conversão dos povos indígenas, mas os meios para conseguir tal propósito. Ele pede informações detalhadas sobre os aspectos geográficos do Cabo Norte,

\footnotetext{
${ }^{13}$ Carta do Governador, Francisco de Sá e Meneses, para o rei sobre as medidas a tomar para se aprisionar os franceses que praticam o resgate de escravos, incluindo gentios, no norte da capitania contra a vontade da coroa portuguesa. Belém, 22 de janeiro de 1685. AHU. Pará, Cx. 3, doc. 245.

${ }^{14}$ VIEIRA, Antônio in: LEITE, Serafim. História da Companhia de Jesus no Brasil, t. III, p. 533.

${ }^{15}$ VIEIRA, Antônio in: LEITE, Serafim. História da Companhia de Jesus no Brasil, t. III, p. 533.

${ }^{16}$ LEITE, Serafim. História da Companhia de Jesus no Brasil, t. III, p. 533.
} 
No ano de 1680, os jesuítas Pier Luigi Consalvi, irmão Manuel Juzarte e o missionário Pfeil visitaram a região. O último em cumprimento da ordem analisou rios, terras e lugares para confeccionar um mapa. Este foi levado em 1685 pelo superior do Maranhão Jódoco Peres e oferecido em Lisboa para o rei. ${ }^{17}$ Ao entrarem no rio Araguari depararam-se com franceses vindos da Guyane que realizavam comércio com os indígenas, possivelmente tráfico fruto de guerras intertribais. ${ }^{18}$ Como estava em vigor a lei de 1680 que concedeu liberdade irrestrita aos indígenas os inacianos pagaram por eles e restituíram a liberdade. Entretanto, admoestaram os franceses de que estavam fora do seu território. Luigi Gonsalvi, que era vice-provincial da Companhia de Jesus no Estado do Maranhão, os mandou embora, mas entregou uma carta ao provincial de Caiena, ao jesuíta Pedro Brano ou Pierre Brane, repudiando a presença dos franceses em terras consideradas portuguesas. ${ }^{19}$ Como sinal de posse construíram um cruz na aldeia de Tabarapixi, onde Aloísio Pfeil ficou como missionário.

Em carta régia de 21 de dezembro de 1686, D. Pedro II escreveu ao Governador do Maranhão pedindo a construção de fortalezas conforme as necessidades de conversão do "gentio", bem como, a posse do território para evitar a presença dos franceses. ${ }^{20}$ Ademais o rei pediu a presença da Companhia de Jesus e a divisão do Cabo Norte entre ela e os Capuchos de Santo Antônio que já estavam em missão. Na missiva ele escreve sobre a função dos jesuítas, “[...] e com o cuidado destes Missionários podereis conseguir que os Missionarios francezes não adquiram a pratica dos Aruazes, e que os Índios não busquem a communicação alheia, esquecidos da propria e natural do meu domínio."21

A perspectiva de D. Pedro II foi a "conservação do Gentio e bem do Estado"22, ou seja, não apenas conquistar o território, mas as pessoas que nele viviam. Sem os povos indígenas, era impensável garantir a posse, principalmente em uma região de fronteira no século XVII em que o trânsito de ameríndios e franceses era livre e há tempos estabeleciam relações comerciais. A partir do pedido real, Gomes Freire dividiu o campo de atuação entre os frades de Santo Antônio e os inacianos da seguinte forma: os

\footnotetext{
${ }^{17}$ LEITE, Serafim. História da Companhia de Jesus no Brasil, t. III, p. 533.

${ }^{18}$ BETTENDORFF, João. Crônica dos Padres da Companhia de Jesus no Estado do Maranhão, 1990.

${ }^{19}$ REIS. Arthur. Território do Amapá, 1949.

${ }^{20}$ Carta régia de 21 de dezembro de 1686 . Instruções ao governador do maranhão sobre relações com os franceses, construção de fortalezas, missões, resgate dos índios.

${ }^{21}$ Carta régia de 21 de dezembro de 1686. instruções ao governador do maranhão sobre relações com os franceses, construção de fortalezas, missões, resgate dos índios.

${ }^{22}$ Carta régia de 21 de dezembro de 1686. instruções ao governador do maranhão sobre relações com os franceses, construção de fortalezas, missões, resgate dos índios.
} 
franciscanos missionavam entre Macapá e rio Amazonas; já os jesuítas missionavam na costa do Cabo Norte. ${ }^{23}$

A carta régia destaca o desejo de impedir que missionários franceses "praticassem" os Aruã que foram historicamente considerados inimigos dos portugueses. Pode-se inferir que os religiosos franceses entravam nas terras do cabo Norte para catequizar os ameríndios. A presença "estrangeira" era uma ameaça real aos portugueses que, a partir de então, decidiram agir com mais veemência por meio da construção de fortes e com o apoio de religiosos. O rei acrescenta que a ida às "terras do Cabo Norte" é para que os "Índios não busquem a communicação alheia" 24 , ou seja, o projeto era de que eles se tornassem as "muralhas dos sertões" ${ }^{25}$. Dessa forma, através de alianças e cooptação dos ameríndios que habitavam os "sertões do Cabo do Norte" seria possível torná-los súditos de Portugal e pertencentes ao rebanho da Igreja.

O governador Gomes Freire escreveu uma carta ao rei em 19 de julho de 1687 dando conta de que tinha enviado o engenheiro, o capitão-mor (Antônio de Albuquerque) e o jesuíta Aloísio Conrado Pfeil ao Cabo do Norte em 2 de junho para analisar um sítio para construção de fortificações. O lugar escolhido foi o rio Araguari "na boca de seus lagos por onde os franceses costumavam entrar em direção ao Amazonas para "comerciar com o gentio." ${ }^{26}$ Estrategicamente a casa forte foi construída no rio Araguari, pois era por ele que os franceses chegavam no rio Amazonas. Neste aspecto também os indígenas foram fundamentais, pois eram com eles que os europeus buscavam saber da realidade, isto é, sobre fenômenos, rios, ventos, presenças de fortes, melhor lugar para construções e povoações.

O capitão-mor do Pará Antônio de Albuquerque escreveu em 19 de julho de 1687 ao rei de Portugal,

[...] Continuando neste meio tempo a penetrar o rio e lagos de Maicari, aonde vivem muitas nações de gentios, cujos principais fiz convocar à aldeia sita no meio de um grande lago chamado Camonixari [...] E vendo que a falta das águas me dificultava a passagem das minhas canoas, e impedia o continuar da dita viagem, penetrando aquele sertão até a costa e paragem aonde houve a dita fortaleza de Maiacari me resolvi a voltar; deixando na dita aldeia de

\footnotetext{
${ }^{23}$ REIS. Arthur. Território do Amapá, 1949.

${ }^{24}$ Carta régia de 21 de dezembro de 1686. instruções ao governador do maranhão sobre relações com os franceses, construção de fortalezas, missões, resgate dos índios.

${ }^{25}$ FARAGE, NÁDIA. As muralhas dos sertões: os povos indígenas no Rio Branco e a colonização. Rio de Janeiro: Paz e Terra; ANPOCS, 1991.

${ }^{26}$ FREIRE, Gomes In: LEITE, Serafim. História da Companhia de Jesus no Brasil, t. III, p. 534.
} 
Camonixari o missionário que levava em minha companhia, por ser ali mais preciso, e o dito gentio mo pedir [...]. ${ }^{27}$

Nesta carta o capitão-mor foi para os "sertões do cabo do Norte" com o jesuíta Pfeil e iniciou relações com "nações de gentios" cujo povo era dos "Maruanizes" e visitou os fortes que os portugueses haviam tomado dos ingleses e holandeses. Ele confirma a dificuldade de navegação pelo rio Araguari e a aproximação do Cabo Norte (um acidente geográfico na costa que servia como referência aos navegadores). Na missiva ele relata a presença de franceses que estavam "comerciando escravos no rio das Amazonas na ilha dos Haroans nas quais tem os religiosos capuchos sua missão" 28 e que compraram escravos no "sertão dos Tocujus, pouco distante da fortaleza de Gurupá."29

Na região de lagos em Maiacari, onde havia uma "multidão" de indígenas, ele estabeleceu contato com as lideranças, os "principais", para viverem em uma missão. A aproximação com os "principais" foi fundamental na Amazônia, sobretudo no momento de implantação do controle político como era o caso das "terras do Cabo Norte". Precisava-se seduzir e cooptar a liderança para torná-la aliada. Aos poucos, as populações indígenas foram se inteirando das disputas entre os europeus e procuravam tirar alguma vantagem para criar possibilidades de autonomia. ${ }^{30}$ Cabia ao líder escolher o local da aldeia, supervisionar as atividades que ele de forma igual aos seus pares participava das ações. Os jesuítas admiravam nos principais a oratória, habilidade essa muito valorizada pelos diversos povos indígenas. Além disso, eles eram responsáveis por guardar as tradições. Esses líderes exerciam poder político e social por meio da persuasão e nem tanto pela coerção. ${ }^{31}$ Por isso os padres visavam cooptá-los através de presentes, pois a possibilidade deles convencerem suas aldeias à morarem nas missões aumentava.

\footnotetext{
${ }^{27}$ Carta de Antônio de Albuquerque Coelho de Carvalho para Dom Pedro II, escrita em Belém, 19 de julho de 1687 encontra-se anexada a Carta do governador [e capitão-general do Estado do Maranhão, Grão-Pará e Rio Negro, Artur de Sá e Meneses, para o rei Dom Pedro II sobre a construção de fortalezas do Cabo do Norte. Belém, 19 de setembro de 1687. AHU. Pará, Cx.3, doc. 267.

${ }^{28}$ Carta de Antônio de Albuquerque Coelho de Carvalho para Dom Pedro II, escrita em Belém, 19 de julho de 1687 encontra-se anexada a Carta do governador [e capitão-general do Estado do Maranhão, Grão-Pará e Rio Negro, Artur de Sá e Meneses, para o rei Dom Pedro II sobre a construção de fortalezas do Cabo do Norte. Belém, 19 de setembro de 1687. AHU. Pará, Cx.3, doc. 267.

${ }^{29}$ Carta de Antônio de Albuquerque Coelho de Carvalho para Dom Pedro II, escrita em Belém, 12 de julho de 1687 encontra-se anexada a Carta do governador [e capitão-general do Estado do Maranhão, Grão-Pará e Rio Negro, Artur de Sá e Meneses, para o rei Dom Pedro II sobre a construção de fortalezas do Cabo do Norte. Belém, 19 de setembro de 1687. AHU. Pará, Cx.3, doc. 267.

${ }^{30}$ CARVALHO JÚNIOR, Almir Diniz de. Índios cristãos: poder, magia e religião na Amazônia colonial. Curitiba: CRV, 2017.

${ }^{31}$ DOMINGUES, Ângela. Quando os índios eram vassalos: colonização e relações de poder no norte do Brasil na segunda metade do século XVIII. Lisboa. Comissão nacional para as comemorações dos descobrimentos portugueses, 2000.
} 
O local escolhido foi "no meio de um grande lago chamado Camonixari." ${ }^{32}$ Nele ficaram os missionários jesuítas Antônio Pereira e Bernardo Gomes. O primeiro foi escolhido para ser superior da missão e o segundo era um jovem padre. A partir da leitura desse documento, é possível perceber que a escolha de onde ficaria a missão não foi aleatória. As escolhas contavam com a participação dos ameríndios, pois, muitas vezes, era uma condição para se aldearem. Eram eles que conheciam o melhor lugar para se viver. Sabiam onde havia abundância de caça e pesca. Por isso o capitão-mor afirma que o lugar foi escolhido por ser "mais preciso" e "o dito gentio mo pedir." 33 Entretanto, a vontade dos indígenas que aparecem na documentação se dava em condições desfavoráveis. A vida na missão era a escolha menos prejudicial, visto que a escravidão e a exploração eram constantes para aqueles que não se aliavam aos portugueses. Ademais, a vida nos aldeamentos era garantia de terras, apesar do tamanho reduzido e os líderes poderiam receber títulos, salários e cargos. ${ }^{34}$

Como relatado anteriormente, o lago/ aldeia de Camonixari foi escolhida para a missão. Sobre ela, João Bettendorrf assevera: "É camunixary uma ilha deserta, povoada de poucas arvores e de pouco préstimo para a vida humana." ${ }^{35}$ Lá ficaram os missionários Antônio Pereira e Bernardo Gomes. O capitão-mor e Aloísio Pfeil retornaram ao Pará sem deixar soldados, pois os inacianos preferiram que os militares não ficassem para não atrapalhar a catequese. ${ }^{36}$ No retorno à Belém eles passaram "pela Aldeia de Tabarapixi, de índios Maraúnus, lugar ameno onde Pfeil já tinha estado e escolhera para futura residência sua, e onde logo, com ajuda dos soldados, edificou a casa que deixou pronta $[\ldots] . " 37$

\footnotetext{
${ }^{32}$ Carta de Antônio de Albuquerque Coelho de Carvalho para Dom Pedro II, escrita em Belém, 19 de julho de 1687 encontra-se anexada a Carta do governador [e capitão-general do Estado do Maranhão, Grão-Pará e Rio Negro, Artur de Sá e Meneses, para o rei Dom Pedro II, sobre a construção de fortalezas do Cabo do Norte. Belém, 19 de setembro de 1687. AHU. Pará, Cx.3, doc. 267.

${ }^{33}$ Carta de Antônio de Albuquerque Coelho de Carvalho para Dom Pedro II, escrita em Belém, 19 de julho de 1687 encontra-se anexada a Carta do governador [e capitão-general do Estado do Maranhão, Grão-Pará e Rio Negro, Artur de Sá e Meneses, para o rei Dom Pedro II, sobre a construção de fortalezas do Cabo do Norte. Belém, 19 de setembro de 1687. AHU. Pará, Cx.3, doc. 267.

${ }^{34}$ ALMEIDA, Maria Regina Celestino de. Os índios na História do Brasil. Rio de Janeiro: FGV, 2010.

${ }^{35}$ BETTENDORFF, João. Crônica dos Padres da Companhia de Jesus no Estado do Maranhão, p. 425.

${ }^{36}$ BETTENDORFF, João. Crônica dos Padres da Companhia de Jesus no Estado do Maranhão, p. 425

${ }^{37}$ LEITE, Serafim. História da Companhia de Jesus no Brasil, t. III, p. 534, itálico no original.
} 


\section{Possível localização das missões jesuíticas no atual Amapá}

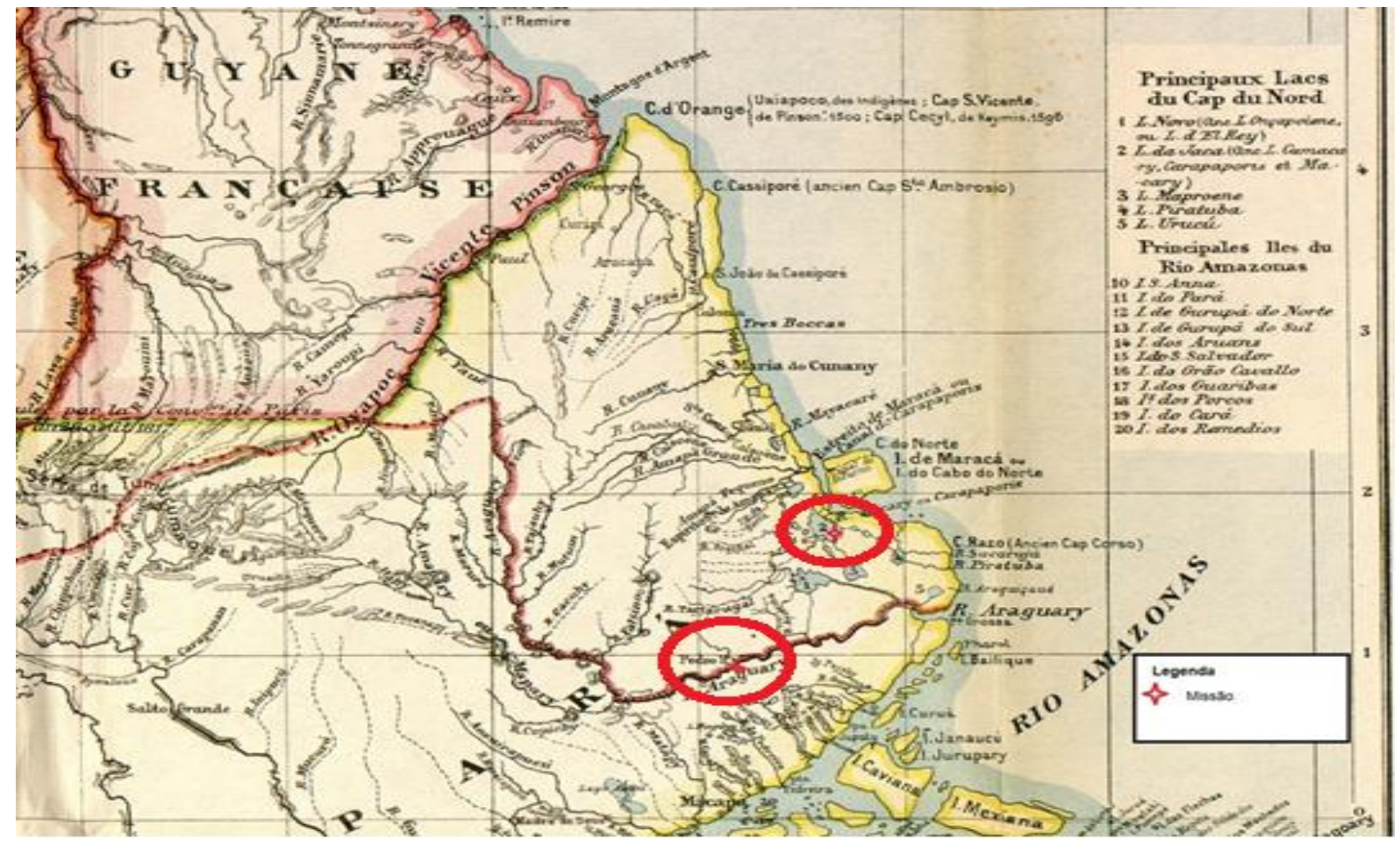

Fonte: RIO BRANCO, Barão do. Obras do barão do Rio Branco III: questões de limites Guiana Francesa primeira memória. Brasília: Fundação Alexandre de Gusmão, 2012. Adaptado pelo autor.

\section{A catequese e o conflito}

Os dois missionários de Camonixari ficaram na casa do principal Macuraguaia que consentiu a presença dos jesuítas e a partir daí iniciaram a atividade apostólica de tentar catequizar os povos da redondeza. ${ }^{38}$ Serafim Leite ${ }^{39}$ destaca a pregação contra a "bebedice" e "poligamia". Os padres tentavam de todas as formas convencer os ameríndios em abandonar as suas práticas culturais. Catequese e a ideia de "civilizar" estiveram lado a lado, pois para os filhos de Loyola somente assim, ou seja, abandonando as suas práticas tidas pelos europeus como "bárbaras" e "selvagens", seria possível tornálos novos homens. ${ }^{40}$ Para sustentar a atividade missionária, os jesuítas iniciaram a construção da igreja, espaço privilegiado para a catequese. Mas algo mudou os rumos dos planos da Companhia para o Cabo Norte no século XVII.

Em novembro de 1687, o capitão-mor, soldados e padre Conrado Pfeil retornaram à região para que o referido missionário ficasse na aldeia de Tabarapixi, onde exerceria sua atividade. Foi lá que foram informados por indígenas das mortes dos dois padres que

\footnotetext{
${ }^{38}$ BETTENDORFF, João. Crônica dos Padres da Companhia de Jesus no Estado do Maranhão, 1990.

${ }^{39}$ LEITE, Serafim. História da Companhia de Jesus no Brasil, t. III.

${ }^{40}$ KERN, Arno Alvarez. Missões: uma utopia política. 2. ed. Porto Alegre: EDIPUCRS, 2015.
} 
havia ocorrido em setembro por grupos indígenas que viviam nas proximidades de Camonixary. O capitão-mor imediatamente mandou averiguar a informação. Antônio Albuquerque enviou uma guarnição para capturar os ameríndios envolvidos. Eles foram encontrados em Maimaimé ou Maiacuré quando tentavam fugir à Guyane. Chama atenção esse aspecto, pois isso indica que eles souberam fazer a leitura de que havia disputas entre as nações e sabiam que ao passar para o território francês, os portugueses não poderiam capturá-los. Exemplo desse fato é que povos Aruã e Maraones foram viver em aldeamentos jesuíticos na Guyane, notadamente na missão de Kourou no início do século XVIII. ${ }^{41}$ Como os portugueses faziam uma política de terror na conquista e no estabelecimento de fortes, foi comum durante a primeira metade do século XVIII grupos ameríndios viverem em missões de jesuítas franceses na região do Oiapoque como forma proteção às "correrias" portuguesas. ${ }^{42}$

Uns conseguiram fugir, outros morreram e alguns foram capturados. Após investigações, a justiça condenou à morte dois envolvidos e outros receberam a pena de degredo para o Maranhão. O rei, em carta de 31 de maio de 1688, agradeceu ao capitãomor pela punição aos Maraunus. ${ }^{43}$ Contudo, Serafim Leite assevera que: "Dois anos depois, deu-se anistia geral aos índios que ainda andavam fugidos por esse e outros crimes." ${ }^{44}$ Provavelmente para evitar que os ameríndios realizassem contatos com os franceses, visto que os europeus estavam em litígio pelo território. Nesse sentido, as populações indígenas seriam fundamentais para consolidação do domínio. Por outro lado é possível deduzir que os ameríndios souberam negociar esse perdão. Ambos possuíam interesses.

De fato, a morte dos padres Antônio Pereira e Bernardo Gomes ficou marcada na memória interna da Companhia de Jesus. Os inacianos utilizaram da retórica do martírio para exaltar o "sacrifício" e "entrega" pela fé dos missionários. Na narrativa tanto do Serafim Leite quanto e principalmente do padre João Bettendorff há exaltação das ações desses sacerdotes. Na narrativa de João Bettendorff, os jesuítas são representados como "ovelhinhas inocentes" e os indígenas como "lobos assanhados." ${ }^{45}$ Os ameríndios, que

\footnotetext{
${ }^{41}$ VERWIMP, Régis. Les jésuites en Guyane Française sous l'Ancien Régime (1498-1768). Matoury: Ibis Rouge Éditions, 2011.

42 Para as missões no Oiapoque: SILVA, Giovani José da; NASCIMENTO, Bruno Rafael Machado. Américas indígenas "periféricas": nativos e jesuítas em Oiapoque e Chiquitania. Revista Habitus, Goiânia, v. 15, n. 1, p. 137-158, jan./jun. 2017.

${ }^{43}$ LEITE, Serafim. História da Companhia de Jesus no Brasil, t. III.

${ }^{44}$ LEITE, Serafim. História da Companhia de Jesus no Brasil, t. III, p. 535.

${ }^{45}$ BETTENDORFF, João. Crônica dos Padres da Companhia de Jesus no Estado do Maranhão, 1990.
} 
eram objeto da catequese dos filhos de Loyola, tentaram convencer o principal Macuraguia dos Maruanizes que deixasse de apoiar os religiosos e os expulsassem. Como não conseguiram, os Oivanecas invadiram a aldeia para matarem os padres. $\mathrm{O}$ principal e a sua comunidade fugiram para não serem mortos. Indígenas se aproximaram do Padre Antônio Pereira que estava na rede lendo um livro e pediram para ele esperar seus parentes que chegariam do mato com alguns presentes. Logo em seguida:

[...] arremetteram logo com os padres, quaes uns lobos assanhados e famintos com umas ovelhinhas innocentes. Quis o padre Antonio Pereira ter-lhes mão e abrandar essa sua fúria por uma pratica que lhes fez, mas elles, fechando as orelhas assim do corpo como da alma a tudo o que lhes convinha, saltaram sobre elles. O primeiro e principal aggressor e matador dos padres foi o principal Canariá, da nação Aguaraca e da aldêa de Coanurú, conforme contou sua própria mulher Aracú, e também dahi vieram os mais. ${ }^{46}$

Após serem capturados a mando do capitão-mor, o principal Canariá contou ao padre Aluisio Pfeil que ele juntamente com cinco companheiros mataram o sacerdote com uma paulada em sua cabeça, contudo, já prestes a morrer, seu irmão Amapixaba deu-lhe o último golpe. Conforme testemunho da esposa do Canariá os outros companheiros eram "Caparipe, Guaruximená, Inaiquerepé e outros mais." 47

As versões sobre o autor ou autores da morte do padre Bernardo Gomes são várias. João Bettendorff munido das diversas possibilidades as expõe da seguinte forma:

\begin{abstract}
Disseram os brancos que o matador dele fora Camayuá, pagé, que quer dizer feiticeiro; porém as testemunhas e principaleza Aracú afirmaram instantemente que o matador do padre Bernardo Gomes fora o Guaruximená, e que todos os mais que tinham morto o Padre Antonio Pereira foram quebrarlhe a cabeça com seus páos ou ybirassangas. ${ }^{48}$
\end{abstract}

Acrescenta o referido autor que também mataram o intérprete Lopo, o piloto Felipe e mais dois rapazes chamados de Antônio e Luiz que juntamente com o piloto eram de uma fazenda pertencente a colégio de Santo Alexandre localizado em Belém, ou seja, eram indígenas aldeados e estavam com os missionários. ${ }^{49}$

O relato das mortes tem o intuito de provocar no leitor o sentimento de piedade para com os padres e ao mesmo tempo edificar os membros da Companhia de Jesus que

\footnotetext{
${ }^{46}$ BETTENDORFF, João. Crônica dos Padres da Companhia de Jesus no Estado do Maranhão, p. 429, grifos nossos.

${ }^{47}$ BETTENDORFF, João. BETTENDORFF, João. Crônica dos Padres da Companhia de Jesus no Estado do Maranhão, p. 429.

${ }^{48}$ BETTENDORFF, João. BETTENDORFF, João. Crônica dos Padres da Companhia de Jesus no Estado do Maranhão, p. 429.

${ }^{49}$ BETTENDORFF, João. BETTENDORFF, João. Crônica dos Padres da Companhia de Jesus no Estado do Maranhão, 1990.
} 
lessem a crônica do padre João Bettendorff. ${ }^{50}$ Dessa forma, as mortes foram retratadas de forma exemplar e espiritual, ou seja, valorizou-se o sacrifício e doação pela fé em Jesus. Os indígenas são considerados os "bárbaros" que não aceitaram a luz da fé. Por isso, logo após as mortes, os indígenas "partiram-nos em pedaços, assando e comendo-os." 51 Além disso, guardaram os crânios para servir de recipiente, e as canelas para "fazerem suas gaitas e pontas de frechas." ${ }^{52}$ Ele continua o relato afirmando que não satisfeitos incendiaram a casa dos padres e do principal Macuraguaia da etnia Maraunizes que havia acolhido os sacerdotes. Fato notório é que em sua crônica ele descreve três grupos indígenas como possíveis matadores dos missionários: “[...] Oivanecas de nação, poz Goamimani, da nação Aricoré, fogo á casa, e o índio Moximaré, da aldeia de Mucará, da gente Maraunizes, com tres outros companheiros surrupiou uma canella do Padre Bernardo Gomes, para dela fazer uma gaita [...]." ${ }^{.53}$

O reitor do colégio de Santo Alexandre em Belém enviou carta datada de 10 e 15 de janeiro de 1688 ao superior geral da ordem em Roma reafirmando as mortes dos jesuítas no Cabo Norte e que eles foram enviados para o "gentio daquela banda sem luz da Fé e sendo vassalos de El Rei de Portugal, se bandeavam com os Franceses de Caiena." 54

Como explicitado anteriormente, os ameríndios foram encontrados em Maimaimé ou Maiacuré. Uns conseguiram fugir, outros morreram e 39 foram capturados. Interessante que ao ir ao encalço dos indígenas estes últimos tentaram manipular os soldados e ameríndios aliados: "andaram por espaço de oito dias enganados pelos guias Maraunizes por brenhas caminhos errados, até que dois meninos naturais daquela terra lhes mostraram o caminho verdadeiro que levava a Maimaime, onde estavam os outros escondidos." ${ }^{55}$ Aqui se percebe as táticas deles ao tentar enganar a tropa que buscava encontrar os envolvidos. Fica evidente que as relações nos "sertões" do Cabo Norte eram complexas. Esses indígenas ao compreenderem os interesses dos colonizadores souberam aproveitar as oportunidades para sobreviverem diante de um cotidiano que os oprimia e

\footnotetext{
${ }^{50}$ TORRES-LONDOÑO, Fernando. Un reino en la frontera, 2000.

${ }^{51}$ BETTENDORFF, João. BETTENDORFF, João. Crônica dos Padres da Companhia de Jesus no Estado do Maranhão, p. 431.

52 BETTENDORFF, João. BETTENDORFF, João. Crônica dos Padres da Companhia de Jesus no Estado do Maranhão, p. 429.

${ }^{53}$ BETTENDORFF, João. Crônica dos Padres da Companhia de Jesus no Estado do Maranhão, p. 43, grifos nossos.

${ }^{54}$ RIBEIRO In: LEITE, Serafim. História da Companhia de Jesus no Brasil, t. III, p. 535.

${ }^{55}$ BETTENDORFF, João. Crônica dos Padres da Companhia de Jesus no Estado do Maranhão, p. 432.
} 
por isso em algumas situações suas táticas inverteram a ordem. ${ }^{56}$ Ao que tudo indica, estes guias Maraunizes teriam ido ao encontro do capitão-mor e diziam serem fugitivos daqueles que haviam assassinado os padres, mas pode ser que eles tenham participado, pois o padre João Bettendorff cita a participação de alguns Maraunizes nas mortes. ${ }^{57}$

Rafael Chambouleyron, Monique Bonifácio e Vanice de Melo ${ }^{58}$ tratam a caçada aos indígenas como uma guerra as chamadas "guerras brasílicas" que, diferentemente das europeias, utilizavam-se de ameríndios e suas técnicas, pois conheciam melhor a região. O pajé Camayuá foi morto pelo capitão Paschoal que era aldeado de Parijó na capitania de Cametá, bem como matou o principal Simão Ingayba que era da aldeia de Cassipurú. ${ }^{59}$ Inclusive os referidos autores citam uma carta do governador Artur de Sá e Meneses sobre a possibilidade da concessão de um "prêmio" a esse indígena pela defesa dos interesses portugueses. Foi feita a consulta pelo Conselho Ultramarino ao rei Dom Pedro II em 28 de setembro de 1688 sobre a mercê que se devia dar ao indígena que matou o principal acusado de ser o promotor das mortes. Segundo este documento, ele tirou a vida do principal que "aleivosamente tirou as vidas dos ditos padres da Companhia missionários no Estado do Maranhão e índios das aldeias de repartição." ${ }^{60} \mathrm{Na}$ mesma documentação o governador argumentou que era o costume no Estado do Maranhão conceder mercês aos indígenas que realizam "ações de valor" e conceder "postos de capitães e sargentos mores nas suas aldeias." ${ }^{61}$ Rafael Chambouleyron, Monique Bonifácio e Vanice de Melo ${ }^{62}$ afirmam que seguindo o parecer do Conselho Ultramarino, o rei autorizou o governador a conceder esses postos aos indígenas.

É possível que o próprio indígena tenha pedido a mercê ao governador do Estado, visto que essa prática foi bastante comum no mundo colonial. Maria Celestino de

\footnotetext{
${ }^{56}$ CERTEAU, Michel. A invenção do cotidiano: artes de fazer. 3. ed. Tradução Ephraim Ferreira Alves. Petrópolis, RJ: Vozes, 1998.

${ }^{57}$ BETTENDORFF, João. Crônica dos Padres da Companhia de Jesus no Estado do Maranhão, 1990.

${ }^{58}$ CHAMBOUleYRON, Rafael; BONIFÁCIO, Monique da Silva; MELO, Vanice Siqueira de. Pelos sertões "estão todas as utilidades": trocas e conflitos no sertão amazônico (século XVII). Revista de História, São Paulo, n. 162, p. 13-49, jun. 2010.

${ }^{59}$ BETTENDORFF, João. Crônica dos Padres da Companhia de Jesus no Estado do Maranhão, 1990.

${ }^{60}$ Carta de Gomes Freire de Andrade, escrita a 22 de setembro de 1688, anexada a "consulta do Conselho Ultramarino ao rei dom Pedro II, sobre a mercê que se deve dar ao índio que matou o principal dos índios. Sobre o pedido de Artur de Sá e Meneses povoar a zona em redor da fortaleza de Cumuaú". Lisboa, 28 de setembro de 1688. AHU. Maranhão, Cx. 7, doc. 802.

${ }^{61}$ Carta de Gomes Freire de Andrade, escrita a 22 de setembro de 1688, anexada a "consulta do Conselho Ultramarino ao rei dom Pedro II, sobre a mercê que se deve dar ao índio que matou o principal dos índios. Sobre o pedido de Artur de Sá e Meneses povoar a zona em redor da fortaleza de Cumuaú". Lisboa, 28 de setembro de 1688. AHU. Maranhão, Cx. 7, doc. 802.

${ }^{62}$ CHAMBOUleYRON, Rafael; BONIFÁCIO, Monique da Silva; MELO, Vanice Siqueira de. Pelos sertões "estão todas as utilidades": trocas e conflitos no sertão amazônico (século XVII). Revista de História, São Paulo, n. 162, p. 13-49, jun. 2010.
} 
Almeida $^{63}$ argumenta que no Rio de Janeiro muitos ameríndios pediam ao rei títulos militares, pois sabiam dos privilégios de possuí-los. A Coroa concedia esses benefícios como forma de estabelecer relações amigáveis com as lideranças indígenas com o objetivo de reforçar o controle do território. Nas "terras do Cabo Norte" essa prática era necessária para "ganhar" os ameríndios, pois era uma região de pouco povoamento e fronteiriça.

Como punição às mortes, outro chefe indígena foi executado a tiro de canhão pelo cabo Matheus dos Santos, comandante do forte Araguari. Antes de ser morto, foi batizado pelo jesuíta Conrado Pfeil com o nome de Francisco Canariá. Seu irmão que foi batizado com o nome de Paulo Amapixaba recebeu a mesma punição em fevereiro de 1689. O ouvidor-mor Miguel da Rosa Pimentel descreve como se deu a execução dos culpados pelas mortes. Segundo ele a sentença não foi somente o degredo, mas os líderes indígenas foram punidos com suas cabeças expostas na aldeia de Camonixary para servir e exemplo aos outros. ${ }^{64}$

Padre Pfeil fez algumas perguntas ao principal Canariá sobre a causa das mortes. Bettendorff com a sua visão de missionário afirma que, por meio de uma intérprete chamada Nathalia (filha de um dos principais dos Maraunizes), ele teria dito que matou o padre Antônio Pereira por conta da tentação do "diabo", e por que o religioso pregava contra seus costumes. Depois foi morto "à boca de uma peça de artilharia..." ${ }^{\circ 5}$ A referida intérprete mediou a conversa do missionário Pfeil com Amapixaba sobre os motivos da morte dos padres. Bettendorff repete a mesma retórica, ou seja, "porque elles e todos os oivanecas de sua nação não queriam ser christãos nem ouvir a lei de Christo..."66

Depois o padre Conrado Pfeil retornou para buscar os ossos dos missionários e com a ajuda de um indígena os encontrou. Em homenagem, realizou uma missa e levantou duas cruzes onde estavam enterrados. Os esqueletos foram levados para Igreja de Santo

\footnotetext{
63 ALMEIDA, Maria Regina Celestino de. Metamorfoses indígenas: identidade e cultura nas aldeias coloniais do Rio de janeiro. 2. ed. Rio de janeiro: Editora FGV, 2013.

${ }^{64}$ Carta do ouvidor-mor Miguel da Rosa Pimentel, escrita em Belém, a 27 de fevereiro de 1688, encontrase anexada na "consulta do Conselho Ultramarino a Dom Pedro II, sobre as informações prestadas pelo ouvidor-geral do Estado do Maranhão, Miguel da Rosa Pimentel, referentes às execuções dos índios acusados da morte de padres da Companhia de Jesus". Belém, 31 de maio de 1688. AHU. Pará, Cx.3, doc. 271.

${ }^{65}$ BETTENDORFF, João. Crônica dos Padres da Companhia de Jesus no Estado do Maranhão, p. 434.

${ }^{66}$ BETTENDORFF, João. Crônica dos Padres da Companhia de Jesus no Estado do Maranhão, p. 434435.
} 
Alexandre em Belém. Segundo Karl Arenz ${ }^{67}$ e Barão do Rio Branco, ${ }^{68}$ as mortes ocorreram em setembro de 1687 e os matadores foram o povo Maracúrios.

Ao consultar documentos sobre essas mortes, o jesuíta Serafim Leite ${ }^{69}$ assevera que na carta régia de 31 de maio de 1688 o rei de Portugal mandou agradecer ao Capitãomor, Antônio de Albuquerque pela ação rápida de prender e castigar os envolvidos. Nesta carta ocorre algo interessante, pois o nome da etnia causadora das mortes é designada de Maraunus. Além disso, na consulta ao Conselho Ultramarino em 17 de maio de 1688, os conselheiros dão razão ao agradecimento do rei pela ação rápida e principalmente pelo impedimento de que os ameríndios passassem para Caiena. ${ }^{70}$

A missão jesuítica no Cabo Norte fracassou e foi abandonada pelo padre Aloísio Pfeil. É o que revela a carta ânua de 1696 escrita por Miguel Antunes após relatar a morte dos missionários: "Foi em seu lugar o P. Aloísio Conrado, religioso de grande zêlo das almas; mas como destes Índios se não esperava fruto algum, e ser de grande detrimento ao Missionários, os largou totalmente e se ocupou em outras missões aonde fez maior fruto." ${ }^{71}$ No ano de 1693 houve uma divisão dos territórios entre as ordens religiosas e o Cabo Norte ficou sob a responsabilidade dos capuchos de Santo Antônio.

\section{Causas da rebelião indígena}

Sabe-se que as populações indígenas criaram várias formas de resistência à dominação portuguesa. No caso em tela dois padres jesuítas foram mortos pelos ameríndios nas "terras do Cabo Norte" em setembro de 1687. O que teria motivado essa ação? Será que os franceses estavam por trás? O desejo de não ser cristão? Ou o medo de não ser escravizado? São várias as possíveis respostas para tentar explicar essa realidade.

Em carta de 13 de outubro de 1691 em resposta ao governador de Caiena Marquês de Ferrolles, o capitão-mor do Pará Antônio de Albuquerque acusou os franceses de terem incitado os indígenas a matar os padres:

[...] Eis o motivo: os quatro franceses que se introduziram nas missões dos padres Capuchinhos na aldeia dos Aruãs cometeram vários atos de violência contra os índios dessa aldeia, que se queixaram; tomaram alguns pela força,

\footnotetext{
${ }^{67}$ ARENZ, Karl Heinz. "Não Saulos, Mas Paulos": uma carta do padre João Felipe Bettendorff da missão do Maranhão (1671). Revista de História, São Paulo, n. 168, p. 271-322, jan/jun. 2013.

${ }^{68}$ RIO BRANCO, Barão do. Obras do barão do Rio Branco III: questões de limites Guiana Francesa primeira memória. Brasília: Fundação Alexandre de Gusmão, 2012.

${ }^{69}$ LEITE, Serafim, 2004, t. III.

${ }^{70}$ Consulta do conselho ultramarino ao rei D. Pedro II. Lisboa, 17 de maio de 1688. AHU. Maranhão, Cx. 7, doc. 798 .

${ }^{71}$ ANTUNES In: LEITE, Serafim. História da Companhia de Jesus no Brasil, tomo III, p. 537.
} 
para submetê-los à escravidão; incitaram outros a guerras injustas para conseguir alguns prisioneiros [...] foram em seguida os promotores do assassinato de dois missionários da Companhia de Jesus por uma tribo de índios que estes padres catequizavam; esses mesmos franceses tendo anteriormente maltratado e insultado grosseiramente esses dois missionários, incitaram os índios a cometer esse crime $[\ldots]]^{72}$

Porém, em uma carta anterior escrita ao rei, o mesmo capitão-mor afirmou que ouviu dos indígenas:

[...] um índio que ficou com o dito padre de Tavatatuba por nome Lopo, que ficou pra intérprete da língua Aruã que o padre tinha, se embebedou e disse aos negros da aldeia que estavam com o padre que se não fizessem do dito padre porque os vinha enganar e só ajuntar para quando eu viesse os levar atados por cativos; também dizem que este negro não só na bebedice disse isto senão sempre porque como ficou com o padre contra a vontade e só queria ir para sua mulher. ${ }^{73}$

$\mathrm{Na}$ missiva ao governador de Caiena, Antônio de Albuquerque acusou os franceses de serem os "promotores do assassinato" dos missionários da Companhia de Jesus. Sua intenção era convencer o Marquês de Ferroles a impedir que franceses viessem ao território reivindicado por Portugal. Já na carta a D. Pedro, ele mudou o conteúdo e culpou o indígena Lopo que era intérprete dos padres na missão. Segundo o capitão-mor, os ameríndios ficaram com receio de serem escravizados e por isso mataram os religiosos.

O que se sabe do intérprete Lopo é que ele dominava a língua portuguesa e isso poderia ter sido a causa da aceitação dos ameríndios. Pode-se pensar tal como Michel de Certeau $^{74}$ no sentido de ser uma tática dele para subverter a ordem imposta. Dentro do jogo das forças foi a situação possível de agir. Lopo aproveitou para inverter a lógica cotidiana mesmo que momentaneamente. Ao longo do texto foi demonstrada a presença francesa na região e os contatos comerciais com os nativos, contudo não se pode afirmar com toda a certeza da influência dos franceses sobre eles.

O governador Artur de Sá de Meneses em carta datada em 9 de fevereiro de 1688 afirmou que havia chegado uma carta do missionário capucho de Santo Antônio que vivia no Cabo Norte dando conta de que os indígenas "Marauanús" tinham matado os inacianos, mas que não tinha certeza. O governador afirmou que foi persuadido e que os incitadores foram os franceses, pois "aquele sertão anda infeccionado" deles. Eles não “toleravam que naquele sítio se façam fortalezas porque lhes impossibilitavam o

\footnotetext{
72 ALBUQUERQUE apud RIO BRANCO, Barão do. Obras do barão do Rio Branco III: questões de limites Guiana Francesa primeira memória. Brasília: Fundação Alexandre de Gusmão, 2012. p. 145.

${ }^{73}$ Cópia da primeira carta de Antônio de Albuquerque coelho de carvalho, escrita em Araguari a 22 de novembro de 1687, encontra-se anexada em "consulta do conselho ultramarino ao rei d. Pedro II". Lisboa, 17 de maio de 1688. AHU, Maranhão, Cx.7, doc. 798.

${ }^{74}$ CERTEAU, Michel. A invenção do cotidiano, 1998.
} 
comércio." 75 Segundo o mesmo documento, o padre Antônio Pereira estava presidindo a missa quando foi morto com seu companheiro. Tentaram fugir para Caiena, mas não conseguiram.

Com olhar religioso, o padre Bettendorff apontou como causa o ódio dos indígenas à fé cristã: "foi o ódio à nossa santa fé e pregação evangélica, com que lhe tiravam seus excessos em beber, seus amancebamentos e ritos gentílicos."76 Aqui ele construiu uma retórica para justificar a ação dos missionários e sua posição foi de que os ameríndios não aceitaram mudar seus comportamentos tão duramente criticados pelos padres. Ao longo do texto do João Bettendorff, tenta-se criar a ideia do martírio, ou seja, morreram por conta da fé cristã.

Na devassa realizada pelo ouvidor-mor Miguel da Rosa Pimentel reconta-se as mortes dos padres e de "quatro índios das aldeias de repartição", uns escaparam e 39 foram presos. "Perguntas judiciais" foram feitas aos indígenas prisioneiros:

[...] uns disseram que por lhe roubarem o que tinham, outros porque lhe proibiram as mulheres e outros porque os franceses lhes praticaram que os padres eram uns embusteiros, o que estavam ali para os entreterem, enquanto não chegava o capitão-mor para que na sua chegada os haviam de amarrar e trazer todos para serem escravos. ${ }^{77}$

Esse documento sintetiza as diversas possibilidades que levaram os grupos indígenas a resistir, mas chama atenção para o medo de serem escravizados pelos portugueses. Concorda - se com Rafael Chambouleyron, Monique Bonifácio e Vanice de Melo $^{78}$ que, devido ser uma região visitada por franceses e portugueses, a possibilidade de que os indígenas usassem isso ao seu favor era considerável. O referido autor chama atenção para uma questão bastante interessante, isto é, da hipótese de que as mortes foram causadas pelos próprios interesses dos nativos. Seria isso pouco provável? Estavam em

\footnotetext{
${ }^{75}$ Carta de Artur de Sá de Meneses, escrita em Belém, a 9 de fevereiro de 1688, encontra-se anexada na "Consulta do Conselho Ultramarino a Dom Pedro II, sobre as informações prestadas pelo ouvidor-geral do Estado do Maranhão, Miguel da Rosa Pimentel, referentes às execuções dos índios acusados da morte de padres da Companhia de Jesus". Belém, 31 de maio de 1688. AHU. Pará, Cx.3, doc. 271.

${ }^{76}$ BETTENDORFF, João. Crônica dos Padres da Companhia de Jesus no Estado do Maranhão, p. 430.

${ }^{77}$ Carta do ouvidor-mor Miguel da Rosa Pimentel, escrita em Belém, a 27 de fevereiro de 1688, encontrase anexada na "Consulta do Conselho Ultramarino a Dom Pedro II, sobre as informações prestadas pelo ouvidor-geral do Estado do Maranhão, Miguel da Rosa Pimentel, referentes às execuções dos índios acusados da morte de padres da Companhia de Jesus". Belém, 31 de maio de 1688. AHU. Pará, Cx.3, doc. 271.

${ }^{78}$ CHAMbOUleYron, Rafael; BONIFÁCIO, Monique da Silva; MELO, Vanice Siqueira de. Pelos sertões "estão todas as utilidades": trocas e conflitos no sertão amazônico (século XVII). Revista de História, São Paulo, n. 162, p. 13-49, jun. 2010.
} 
seus territórios há anos e de repente estrangeiros vêm lhes "propor" ou impor outro estilo de vida, bem como, a possibilidade de se tornarem escravos. Será que isso é impensável?

O fato é que eles não aceitaram a condição de submissão. Acostumados a estabelecer contatos comerciais com outros europeus perceberam que os portugueses buscavam se estabelecer de forma duradoura e que suas práticas eram violentas. Por outro lado, no campo espiritual não se deram por vencidos ao recusarem abandonar as suas práticas.

\section{Considerações finais}

Percebeu-se ao longo do texto a relação entre o Estado e a Companhia de Jesus nas "terras do Cabo Norte" na década de 1680. O quanto o braço religioso foi importante na conquista do território, bem como de suas gentes. Contudo valorizou-se as ações dos indígenas enquanto também protagonistas do processo histórico. De fato, não é possível a partir da documentação afirmar a motivação dos ameríndios para matarem os missionários, mas inclinou-se para a valorização dos seus próprios interesses, mesmo que os agentes coloniais imputassem aos franceses.

Outro aspecto inconclusivo são as etnias que estiveram envolvidas nas mortes. São vários os etnônimos atribuídos aos indígenas que participaram das mortes dos padres. Os testemunhos dão conta que eram os Oivaneca, Aguaraca, Aricoré, Maraunizes, Marauanús, Maracúrios. Eles foram agrupados em vários grupos étnicos em que a grafia varia nas fontes. Essa é uma questão difícil de resolver, pois um etnônimo pode referir-se a várias etnias ou vários etnônimos podem se referir a um único grupo étnico. ${ }^{79}$ Esses termos étnicos foram designados pelos portugueses e não significa que correspondia a realidade dos nativos. Também os indígenas apropriavam-se dessas designações para alcançar seus interesses. Seja em alianças com os portugueses e com os franceses que constantemente entravam nessa região. Além, é claro, com os outros povos indígenas com os quais possivelmente se fundiram.

É o que se pode inferir também a partir da análise do mapa (observe abaixo) do Curt Nimuendajú (2017), pois há vários povos (Aricari, Marauni, Oiavaneca, Maraon) com designações semelhantes às contidas nos documentos analisados.

\footnotetext{
${ }^{79}$ FARAGE, NÁDIA. As muralhas dos sertões, 1991.
} 


\section{Imagem 3- Indígenas que viveram no atual Amapá e Guiana francesa}

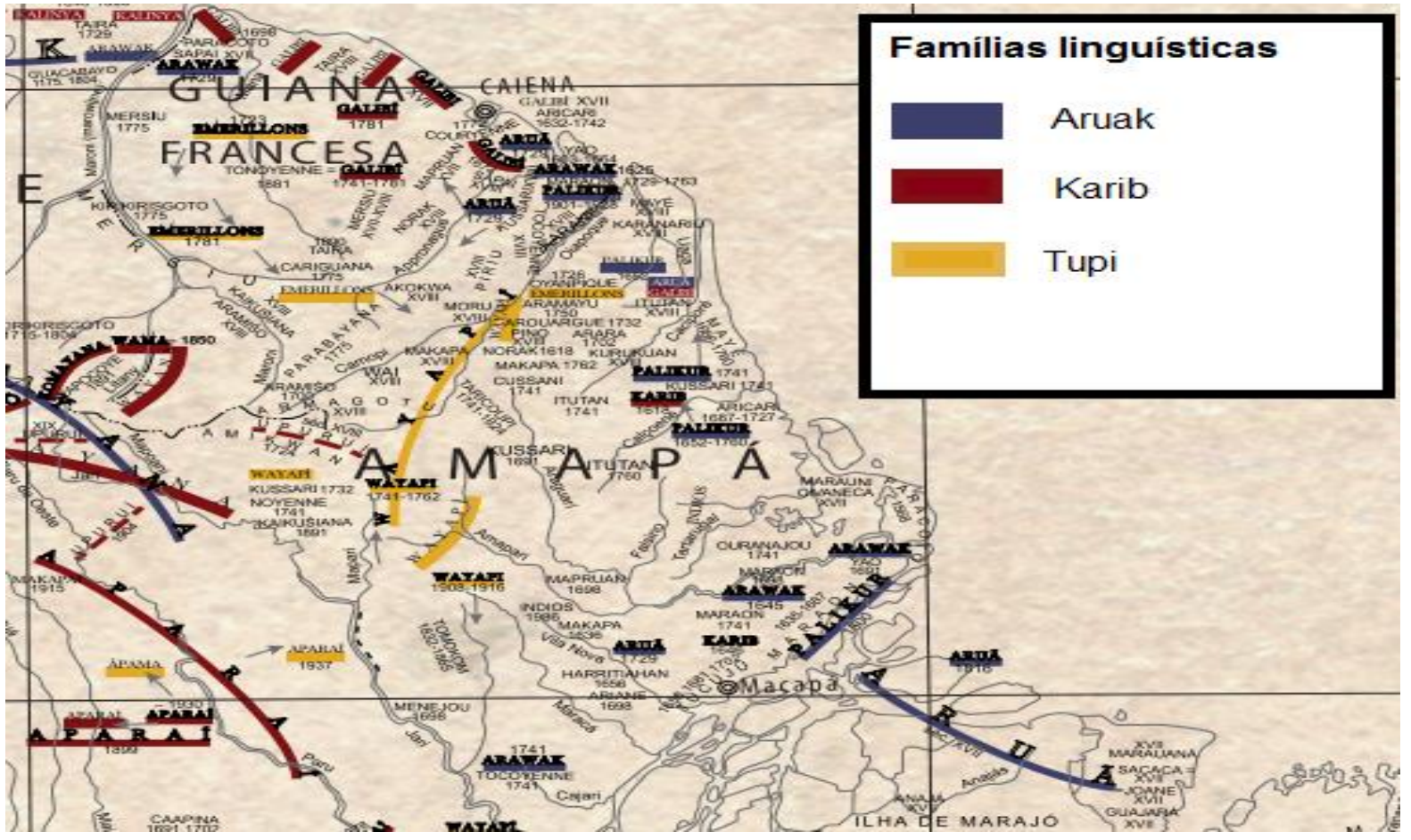

Fonte: NIMUENDAJÚ, Curt. Mapa etno-histórico e regiões adjacentes. Brasília: IPHAN, IBGE, 2017. Adaptado.

Portanto, os ameríndios tentaram das formas possíveis criar táticas para sobreviverem no mundo colonial que lhes foi imposto. Souberam fazer a leitura da realidade diante das disputas entre os europeus. Estabeleceram relações com eles e entre si. Se considerar os envolvidos nas mortes dos jesuítas povos distintos, infere-se que houve alianças entre as etnias para não deixarem de viver as suas práticas culturais e para não serem escravizadas. Eles lutaram para não serem mortos, mas é inegável a violência da colonização que gerou a extinção ou a fusão desses povos. Atualmente o Estado do Amapá não abriga indígenas com as designações presentes nas fontes analisadas, mas é possível que determinados povos que vivem neste Estado sejam frutos das fusões desses e de outros grupos. Já os jesuítas retornarão no século seguinte, inclusive no território em litígio depois da expulsão do império português em 1759 por Pombal. ${ }^{80}$ Porém este é tema para pesquisas posteriores.

Data de Submissão:27/08/2019

Data de Aceite: 29/04/2020

\footnotetext{
${ }^{80}$ Para maiores informações consultar: DOMINGUES, Ângela. Quando os índios eram vassalos, 2000.
} 


\section{Referências Bibliográficas}

ALMEIDA, Maria Regina Celestino de. História e antropologia. In: CARDOSO, Ciro Flamarion; VAINFAS, Ronaldo. Novos domínios da História. Rio de Janeiro: Elsevier, 2012. p. 151-168.

ALMEIDA, Maria Regina Celestino de. Os índios na História do Brasil. Rio de Janeiro: FGV, 2010.

ALMEIDA, Maria Regina Celestino de. Metamorfoses indígenas: identidade e cultura nas aldeias coloniais do Rio de janeiro. 2. ed. Rio de janeiro: Editora FGV, 2013.

APOLINÁRIO, Juciene Ricarte. Documentos e instrumentos de pesquisa de História indígena e do indigenismo d'aquém e d'além-mar Atlântico: uma discussão "necessária, urgente e inadiável. In: Simpósio Nacional de História da ANPUH, 26, 2011, São Paulo. Anais. São Paulo: ANPUH, 2011. p. 1-15. Disponível em: <http://www.snh2011.anpuh.org/resources/anais/14/1308185399_ARQUIVO_TextoJuc ieneRicarteApolinarioUFCG2anexo.pdf >. Acesso em: 05 nov. 2017. p. 2.

ARENZ, Karl Heinz. "Não Saulos, Mas Paulos": uma carta do padre João Felipe Bettendorff da missão do Maranhão (1671). Revista de História, São Paulo, n. 168, p. 271-322, jan/jun. 2013.

BETTENDORFF, João Felipe. Crônica dos Padres da Companhia de Jesus no Estado do Maranhão. Belém: Fundação Cultural do Pará Tancredo Neves/Secretaria de Estado da Cultura, 1990.

CARVALHO JÚNIOR, Almir Diniz de. Índios cristãos: poder, magia e religião na Amazônia colonial. Curitiba: CRV, 2017.

CERTEAU, Michel. A invenção do cotidiano: artes de fazer. 3. ed. Tradução Ephraim Ferreira Alves. Petrópolis, RJ: Vozes, 1998.

CHAMBOULEYRON, Rafael; BONIFÁCIO, Monique da Silva; MELO, Vanice Siqueira de. Pelos sertões "estão todas as utilidades": trocas e conflitos no sertão amazônico (século XVII). Revista de História, São Paulo, n. 162, p. 13-49, jun. 2010. Disponível em: <https://www.revistas.usp.br/revhistoria/article/view/19150>. Acesso em: 30 oct. 2017.

DOMINGUES, Ângela. Quando os índios eram vassalos: colonização e relações de poder no norte do Brasil na segunda metade do século XVIII. Lisboa. Comissão nacional para as comemorações dos descobrimentos portugueses, 2000.

FARAGE, NÁDIA. As muralhas dos sertões: os povos indígenas no Rio Branco e a colonização. Rio de Janeiro: Paz e Terra; ANPOCS, 1991.

GINZBURG, Carlo. Sinais: raízes de um paradigma indiciário. In: GINZBURG, Carlo. Mitos, emblemas, sinais: morfologia e história. Tradução Frederico Carotti. São Paulo: Companhia das Letras, 2001. p. 143- 179. 
KERN, Arno Alvarez. Missões: uma utopia política. 2. ed. Porto Alegre: EDIPUCRS, 2015.

LEITE, Serafim. História da Companhia de Jesus no Brasil. Tomos II, III e IV, São Paulo: Edições Loyola, 2004.

MONTERO, Paula. Introdução. In: MONTERO, Paula (Org.). Deus na aldeia: missionários, índios e mediação cultural. São Paulo: Globo, 2006. p. 9-29.

NEUMANN, Eduardo. Fronteira e identidade: confrontos luso-guarani na Banda Oriental 1680-1757. Revista Complutense de História da América, Madri, v, 26, p. 73-92, 2000 Disponível <https://revistas.ucm.es/index.php/RCHA/article/view/RCHA0000110073A/28733 > Acesso em: 18 dez. 2016.

NIMUENDAJÚ, Curt. Mapa etno-histórico e regiões adjacentes. Brasília: IPHAN, IBGE, 2017.

REIS. Arthur Cezar F. Território do Amapá: perfil histórico. Rio de Janeiro: Imprensa Nacional, 1949.

REIS. Arthur Cezar F. Limites e demarcações na Amazônia brasileira: a frente colonial com a Guiana Francesa. 2. ed. v.1. Belém: SECULT, 1993.

RIO BRANCO, Barão do. Obras do barão do Rio Branco III: questões de limites Guiana Francesa primeira memória. Brasília: Fundação Alexandre de Gusmão, 2012.

SILVA, Giovani José da; NASCIMENTO, Bruno Rafael Machado. Américas indígenas "periféricas": nativos e jesuítas em Oiapoque e Chiquitania. Revista Habitus, Goiânia, v. 15, n. 1, p. 137-158, jan./jun. 2017. Disponível em: $<$ http://revistas.pucgoias.edu.br/index.php/habitus/article/view/5934/3248 > . Acesso em: 31 out. 2017.

TORRES-LONDOÑO, Fernando. La experiencia religiosa jesuita y la crónica misionera de Pará y Maranhão en el siglo XVII. In: NEGRO, Sandro; MARZAL, Manuel (coord.). Un reino en la frontera: las misiones jesuitas en la América colonial. Quito, Ecuador: ABYA-YALA, 2000.

VERWIMP, Régis. Les jésuites en Guyane Française sous l'Ancien Régime (14981768). Matoury: Ibis Rouge Éditions, 2011.

\section{Fontes}

Carta de Antônio de Albuquerque Coelho de Carvalho para Dom Pedro II, escrita em Belém, 19 de julho de 1687 encontra-se anexada a Carta do governador [e capitão-general do Estado do Maranhão, Grão-Pará e Rio Negro, Artur de Sá e Meneses, para o rei Dom Pedro II sobre a construção de fortalezas do Cabo do Norte. Belém, 19 de setembro de 1687. AHU. Pará, Cx.3, doc. 267.

Carta de Antônio de Albuquerque Coelho de Carvalho para Dom Pedro II, escrita em Belém, 12 de julho de 1687 encontra-se anexada a Carta do governador [e capitão-general 
do Estado do Maranhão, Grão-Pará e Rio Negro, Artur de Sá e Meneses, para o rei Dom Pedro II sobre a construção de fortalezas do Cabo do Norte. Belém, 19 de setembro de 1687. AHU. Pará, Cx.3, doc. 267.

Carta de Artur de Sá de Meneses, escrita em Belém, a 9 de fevereiro de 1688, encontrase anexada na "Consulta do Conselho Ultramarino a Dom Pedro II, sobre as informações prestadas pelo ouvidor-geral do Estado do Maranhão, Miguel da Rosa Pimentel, referentes às execuções dos índios acusados da morte de padres da Companhia de Jesus". Belém, 31 de maio de 1688. AHU. Pará, Cx.3, doc. 271.

Carta de Gomes Freire de Andrade, escrita a 22 de setembro de 1688, anexada a "consulta do Conselho Ultramarino ao rei dom Pedro II, sobre a mercê que se deve dar ao índio que matou o principal dos índios. Sobre o pedido de Artur de Sá e Meneses povoar a zona em redor da fortaleza de Cumuaú". Lisboa, 28 de setembro de 1688. AHU. Maranhão, Cx. 7, doc. 802.

Carta do Governador Francisco de Sá e Meneses, para o rei sobre as medidas a tomar para se aprisionar os franceses que praticam o resgate de escravos, incluindo gentios, no norte da capitania contra a vontade da coroa portuguesa. Belém, 22 de janeiro de 1685. AHU. Pará, Cx. 3, doc. 245.

Carta do ouvidor-mor Miguel da Rosa Pimentel, escrita em Belém, a 27 de fevereiro de 1688, encontra-se anexada na "consulta do Conselho Ultramarino a Dom Pedro II, sobre as informações prestadas pelo ouvidor-geral do Estado do Maranhão, Miguel da Rosa Pimentel, referentes às execuções dos índios acusados da morte de padres da Companhia de Jesus". Belém, 31 de maio de 1688. AHU. Pará, Cx.3, doc. 271.

Carta régia de 21 de dezembro de 1686. Instruções ao governador do maranhão sobre relações com os franceses, construção de fortalezas, missões, resgate dos índios. Disponível em: $<\underline{\text { http://www.iuslusitaniae.fcsh.unl.pt/verlivro.php?id_parte }=103 \& i d \_o b r a=63 \& \text { pagina }=}$ 262>. Acesso em: 10 nov. 2017.

Consulta do conselho ultramarino ao rei D. Pedro II. Lisboa, 17 de maio de 1688. AHU. Maranhão, Cx. 7, doc. 798.

Cópia da primeira carta de Antônio de Albuquerque coelho de carvalho, escrita em Araguari a 22 de novembro de 1687, encontra-se anexada em "consulta do conselho ultramarino ao rei d. Pedro II”. Lisboa, 17 de maio de 1688. AHU, Maranhão, Cx.7, doc. 798. 